\title{
ライフコース研究におけるデー夕構築の特質
}

\section{Data Organization for Life Course Research}

\section{澤口恵一 SAWAGUCHI Keiichi}

This essay discusses the issue of data management in life history research. Frequently asked questions in life course research include the status of the individual at a specific time , and what kind of household or organization she or he belonged to at the time. This essay illustrates that Relational Database Management System (DBMS) is the ideal tool for efficient data-management in life course research, using as an example our research project, "The Discharge of Four Thousand Coal Minners of Jyoban Tanko K.K”. This essay suggests that designing an appropriate database leads to improved conceptualization in the data analysis stage.

\section{1.はじめに}

ライフヒストリー・データを利用した研究は、理論、測定法、分析法、データマネージ メントそれぞれの分野で、近年急速な発展をとげてきた。理論の面においては、ライフコ 一ス論によって、社会変動と個人の多岐にわたるキャリア間の相互関係に接近していくこ との重要性、およびそのために必要な概念枠組みの整備がすすめられた [Bengtson \& Allen 1993]。測定法の面では、回顧法によるデータの信頼性に対する疑問が指摘され [Scott \& Alwin 1999]、パネル研究や回顧法の信頼性を向上させる新たな調査技法や用具 が開発されてきたし [Brückner \& Mayer 1999,Freedam et al 1988]、またアーカイブデー 夕を利用して世帯や個人のライフヒストリーを復元していくアプローチが大きな成果をあ げてきた[Elder et al 1993]。さらに分析技法の側面では、出来事経験の発生率を左右す る要因を説明するイベントヒストリー分析やプロビット分析などの手法が発達してきた [Heaton \& Vaughn 1995]。ここではこれらに加えて、データマネージメントの側面にお いて、ライフヒストリー・データに特有の課題があることを指摘する。

分析課題に応じたデータマトリックスを構築することは、社会調査法の概説書において も、社会学的研究における重要なプロセスの一つとして位置づけられている [中道 1997]。 この場合、一つの社会調査によって構築されたデータは、一つのデータマトリックスとし て表現されることが通常である。したがって、データマトリックスの構筑法に関する議論 が、高度に領域の細分化が進んだ現代の社会学的研究において、それ自体が専門的なトピ ックとして論じられることは稀である。しかしながらライフコース・パースペクティブの 出現とその発展は、一連の調査研究から、複数のデータマトリックスを抽出し管理する必 要を生じさせた。このパースペクティブに特有の分析課題が、従来ではありえなかったデ ータ・マネージメント上の課題をもたらしたためである。本稿では、こうした課題をまず データの特質という観点から明らかにし、その実証研究の過程で必要となる実践をリレー ショナル・データベースの活用という点から論じたい。 
筆者の参加している早稲田大学の研究グループは、現在、常磐炭砿の大閉山によって大 量に発生した離職者たちの追跡調査を行っている [正岡他編 1998,1999]。われわれは、 解雇された労働者約 4,700 名の所在をつきとめ、閉山後の職業キャリアと家族キャリアを 尋ねるとともに、福島大学地域研究七ンターに寄贈された大量な資料をもとに、彼らの家 族や職業キャリアを再構成しようとしている。

こうした研究を進める上では、元労働者たちの現在の所在を追跡するための作業一つ まり現住所を知る手掛かりとなる各種の名簿と離職者のリストを照合する作業、回顧法に よる面接調査のデータ・マネージメント、さらに会社や労働組合によって作成された個人 属性を知ることのできる資料を複数の時点にわたって連結する作業が伴う。

こうしたデータ・マネージメントの技法について述べられた文献はあまりなく、成果は 論文ではなく、むしろ共同研究のために開催されたワークショップで発表されたり、イン ターネット上でドラフトとして公開されているケースが多い(1)。しかし近年、圥長で複雑 なライフヒストリー・データを簡潔に表現するためのアルゴリズムが論文として報告され ることもあり [Otto \& Call 1990]、関心と必要性が高まりつつある領域であるといえよ う。このテーマを早くから手がけてきた研究者はNancy Karweitである。彼女は、自ら携 わったカサレッチョ・プロジェクト—18世紀後半から20世紀前半にかけて、イタリアの 小都市カサレッチョに生じた社会変動が、世帯構成や人々の人生経験にもたらした影響を 明らかにした研究 [Kertzer \& Hogan 1989] 一一事例をあげつつ、ライフコース研究に おけるデータ・マネージメントがもつ固有の問題とカサレッチョ研究において行ったデー タ・マネージメントの方法について論じている [Karweit 1999] (2)。

そこでのKarweitの考えによれば、こうしたデータの組織化についての考察は、単にデ 一夕処理を効率的にするだけにとどまらず、研究者に概念化の作業をせまる良い機会を提 供してくれる（同：97)。この指摘に従いつつ、以下の考察ではライフコース研究におけ るデータ構築の特質に焦点を当てる。

以下の節において、つぎのような議論を展開したい。ライフコース研究に限らず、デー

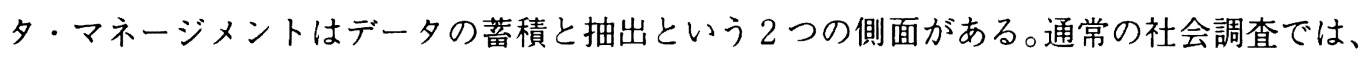
データ・マネージメントにおけるこの 2 つ側面は、分析用のデータマトリックスの設計 という問題とほほ同義である。分析者は調査票の設計どおりに、変数のリストを一つ一つ の列へと置き換えていけば、分析に取り組めるデータマトリックスを得ることができる。 したがって、蓄積と抽出の過程が意識されることはほとんどない。しかし、ライフコース 研究に要求される複雑なデー夕を管理するためには、データの蓄積とデータの抽出を別の 過程として分けることが必要となる。つまり分析の目的に応じたデータマトリックスを、 自由に抽出することができるようなデータの蓄積を行うことが求められる。

本論文の前半では、これをライフコース・パースペクティブのもつ固有の分析視点がも たらす帰結としてとらえたい。また、こうした複雑なデータ・マネージメントを行う際に は、リレーショナル・データベースシステムの利用が不可欠である。論文の後半では、実 際にわれわれが行っている調査の事例をあげることによって、データベースの設計法につ いて簡単に触れたい。 


\section{2. ライフコース研究におけるデータの特質}

ライフコース研究に特有なデータ・マネージメント上の課題を論じるにあたって、まず ライフコース研究で扱われるデータの性質について、次の $2 つ の$ 水準から類別をして論じ る必要があるだろう。

第一にライフコース研究におけるデータ・マネージメントの特質は、その分析枠組みの 特徴である、複数の分析単位への視点、イベントヒストリー分析によるアプローチ、複数 のキャリア間の関連への関心、多元的な時間軸の概念化から生じている。第二にデータの 源泉という視点から、回顧法によるライフヒストリー・データ、追跡法によるパネルデー 夕、行政や企業が作成した資料を二次的に利用するアーカイブデータなど、資料の性質か ら生じる違いについて言及ができよう。しかし本稿では、第一の課題のみについてとりく むことにする。

\section{(1) 複数の分析単位}

ライフコース研究においては、一つのデータセットの分析に扱われる分析単位が複数で あることが多い。もっともよくある例は、カサレッチョ・プロジェクトでもあつかわれて いる世帯水準と個人水準である。カサレッチョの研究では、1865年から1921年にそこに居 住していた19,000人のライフヒストリーをさまざまな行政資料から再構成することで、個 人がいつ、どの世帯に属しているのかを時系列でとらえることができた。社会変動にとも なうライフイベントの変動を研究しようとする際に、個人をとりまくもっとも身近なコン テクストとして、世帯は非常に重要な分析単位となる。たとえば、ライフコースの変動を 理解する上では、ある歴史上の時点における世帯類型の分布や世帯員数が関心とされる。

世帯を一時点でのみ観察する横断的データでは、こうした世帯の人口学的属性に関する 分析視点は、観察された 1 時点でのスナップショットとなる。これに対して、カサレッチ ヨ・プロジェクトのように世帯を通時的に観察することができる場合、世帯における個々 の世帯員の移動を記述することができる。カサレッチョ研究では個々の成員の参入（誕生 や結婚などによる転入）と離脱（死亡や離家）、あるいは新しい世帯の形成や消隇を再構 成することが必要であった。そのさいに分析視点に応じて、個人水準についてのデータマ トリックスと、世帯を分析するためのデータマトリックスを別に用意することが必要とな る(3)。

\section{（2）イベントヒストリー・データによる人生経験の記述}

ライフコース研究では通常、ライフヒストリーを出来事の配列として捉え、出来事経験 の内容とともにその出来事が生じた時点を記述していく。出来事が生じた時点は、ある状 態への移行がなされてから、その状態が持続する期間としてとらえることができよう。こ のようなデータはイベントヒストリー・データと呼ばれる [Heaton \& Vaughn 1988]。

たとえば結婚に関連した出来事について尋ねた調査から作られるイベントヒストリー・ データでは、結婚、別居、離死別、再婚といった出来事経験の有無と、それぞれを経験し た年月が尋ねられる。このようにして表現されたイベントヒストリーは、キャリアとも呼 ばれる。

イベントヒストリー・データを収集する際に、通常の質問形式と異なるのは、出来事経 
験の回数に原則として制約をもうけないことである。結婚キャリアを例に考えてみても、 結婚、離死別の経験回数はさまざまである。通常データマトリックスの構築法では、生じ た出来事の最大数の分だけ列を設定し、そこに出来事経験についてのデータを入れること になろう。ただし、こうしたデータマトリックスの構築法には次のような問題が生じるこ とになる。第一にデータマトリックスの設計段階では、ある出来事経験の回数の最大值が 既知であることはむしろ稀である。回顧法によって一時点で収集されたデータであれば、 それは不可能ではないが、パネル調査の場合、出来事経験の回数の最大值をあらかじめ知 ることはできない。従って、このようにデータを管理しょうとする場合、デー夕を収集す る度に、頻繁にデータマトリックスのデザインを変更されることを余儀なくされる。

こうしたデータマトリックスによってデータを管理することの第二の問題点は、コンピ ユータ上のリソースを非常に非効率的に使用せざるを得ないことである。出来事経験の最 大数の变数をデータマトリックス上に用意するとすれば、ごく一部の人々しか経験しない 出来事経験（たとえば 4 回目の結婚について）について、ほとんどのケースに非該当のコ 一ドを割り当てなければならない。われわれの常磐炭硡の元砿員に関する職業キャリアの 研究では、元労働者たちが閉山後に経験した職業の最大数は 8 職である。しかし、第 8 職 への就職経験者数は、現在までに収集されたデータの中では全373名のうち 1 名のみに過 ぎい。このような形式でデータを保存していけば、当然データのサイズが非常に大きく なるばかりでなく、統計パッケージソフトや表計算ソフトが扱える変数（アプリケーショ ンソフトでは列あるいはフィールドとも呼ばれる）の上限を超えることがある。コンピュ 一タで利用できるアプリケーションソフトの仕様の制約は、こうした形式でデータの蓄積 にともなう第三の問題である。たとえば常磐炭砿の閉山離職者研究では、閉山後についた 職業のそれぞれについて、栾数で換算すれば103項目に及ぶ質問をしている（職種、就業 時間、開始年月など)。職数の最大数である $8 つ の$ 職業について、それぞれこれらのデー

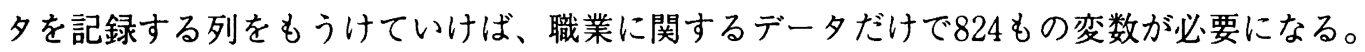

もちろんコンピュータ上のデータマトリックスのデザインを変えること自体は通常の横 断的データの分析でも頻繁に行われることであるし、リソースの非効率的利用やアプリケ ーションソフトによる仕様上の制約は、パーソナル・コンピュータの目覚ましい発達とと もに大きな問題ではなくなりつつある。しかしながら、通常のデータマトリックスの設計 法によってイベントヒストリー・データを格納するさいに生じる、さらに大きな問題が別 にある。もっとも深刻なのは、こうして格納されたデータでは基本的な変数をつくるのに も複雑な操作が必要になることである。第 1 職から第 8 職までの職業について、それぞれ の内容を記述したデータに列を割り当てたデータマトリックスを完成させたとしよう。 8 職あるうちのどの列に現職の内容が記録されているのかは、ケースによって異なる。分析 者が現職についての集計を行う場合には、現職についてのデータを集めた合成变数を別途 作成（現職の有無、現職の職種業種など）しなくてはならない。

以上のような問題点からもあきらかなように、観察される事象（多くの場合質問項目） と変数がほほ一対一の対応関係にある通常のデータ・マネージメントとは、全く異なる方 法がライフコース研究では求められる。 


\section{（３）キャリア間の関連性への関心}

ライフコースの研究者が分析の焦点に据えていることのひとつにキャリア間の出来事経 験の関連性がある。ある出来事と、それとは異なる系に属すキャリア上の出来事の生起、 あるいは夕イミングや配列には、どのような関連性がみられ、時代とともにどのような変 化が生じているのだろうか。もっとも頻繁に取り上げられているトピックは家族キャリア と職業キャリアとの関連である。たとえば、常磐炭砿の閉山離職者の研究では、閉山直後 の職業キャリアの再形成を強いられた時期、および定職からの離脱時期、職業キャリアか らの離脱時期について、主な関心をむけている。これらの職業キャリア上の節目に、彼ら の家族はいかなる状態にあったのだろうか。それによって就労の必要性が大きく異なるこ とが予想される。

では、こうしたキャリア間の関連性を検討することによって生じるデータ・マネージメ ント上の課題にはどのようなものがあるだろうか。イベントヒストリー・データを作成す るさいには、対象者の生年月をあらかじめ明らかにした上で、キャリア上の出来事経験に ついて、それが発生した年月を特定していく。したがって、エディティングが終了した段 階で研究者が利用することができるのは、キャリアの領域に生じた出来事経験の有無、そ の内容、時点を、出来事経験の回数分記録したデータである。このようなデータを上に述 ベたような出来事経験数の分だけ変数を用意して記録していった場合、キャリア間の関連 性を特定することは困難を極める。

たとえば職業キャリアからの離脱時期とその仕事（最後についた職業）の概要（たとえ ば就労時間）が、子どもの巣立ちの状態といかなる関連をもつのかを明らかにしたいとし よう。実際に、常磐炭砿の離職者研究の主要なテーマの一つである、職業キャリアからの 離脱過程を説明するさいに考慮すべき、主な要因の一つは、子どもの巣立ち状態である。 子どもの扶養による負担から解放されることが、職業キャリアからの離脱を規定するもっ とも大きな要因のひとつになるだろうと予想できる。子どもの巣立ち状態を操作的に定義 するためには、離職者のもつすべての子どもについて、学卒、就職、結婚といったライフ イベントが経験済みであるか、経験済みであるとすれば、いつの時点であったのかを特定 する必要がある。子どもの扶養負担からの解放を測るための尺度として、われわれが現在 利用しているのは、家族キャリアにおけるはじめての（第一子のではない）子どもの学 卒・就職・結婚、および最後の（末子のではない）子どもの学卒・就職・結婚である。こ れらを職業キャリアからの離脱過程の分析のための説明変数として利用するためには、少 なくとも次のような操作が必要となる。まず、すべての子どもについて以上の 3 つのライ フイベント経験の有無とそれぞれの出来事についての経験年月の変数をつくる。さらに職 業キャリアからの離脱状態を定義するために、個々のケースについて、定職および職業キ ヤリアからの離脱経験の有無、それぞれの経験年月を特定する変数を作成する必要がある。 こうしてできた職業キャリアと家族キャリアのデータを組み合わせて、大閉山による解雇 の時点、定職からの離脱時点、および職業キャリアからの離脱時点、それぞれにおいて、 個々のケースが子どもの巣立ちをどの程度完了させていたのかを知るための、合成変数を 作成しなければならない。

このように分析のためのデータマトリックスを作成する段階で、さらに複雑な操作が求 められるのである。ひとつのキャリアのみならず、キャリア間の関連性を分析課題とする 
ときには、関心のあるキャリアのすべてにおいて生じた出来事とその内容、経験時点を、 一つ一つの変数に記録していく方法には、データの管理およびデータマトリックスの作成 の両面において、大きな問題があるといえよう。

\section{(4) 多元的な時間軸の概念化}

ライフコース研究における分析視点の特徵のひとつは、分析に利用される時間軸の多元 性である。ライフコース研究に必要となる分析視点として、少なくとも次のような時間軸 が存在する。一つは時間を規準とした歴史時間である。たとえば常磐炭矿離職者の研究で いえば、閉山から 1 年後の1972年 4 月に、どの程度の離職者が再就職をしていたのかを集 計するさいの基準点は、歴史時間におかれている。第二の概念は、個人の暦年齢を基準と する個人時間である。60歳時、70歳時点での巣立ちの完了状態に注目する際には、年齢と いうさまざまな歴史時間上における個人時間に焦点がおかれている。第三の時間概念は、 出来事経験を基準とした時間である。キャリア間の関連性を検討する際には、必然的にこ の次元の時間軸を利用することになる。たとえば、子どもの巣立ちの完了時点（われわれ の操作的定義によれば最後の子どもの結婚）は、個々人によって異なる歴史時間、個人時 間上で経験される。このほかにも、閉山から初めての転居、持ち家取得時、母親・父親の 死亡時といったさまざまな出来事経験をしたときに、どのような従業上の地位、職種にあ ったのかといった分析視点がとりうるだろう。

以上に示した時間軸の多元性からも、単純なデータマトリックスではデータを管理しき れない事態が生じる。出来事経験ごとに変数を用意したデータマトリックスから、上にあ げた 3 つの時間概念に応じた合成変数を作成するのは、あまりにも複雑な操作を必要とす るからである。この点においてもライフコース研究においては、分析の単位・水準・視点 に応じた複数のデータマトリックスが、一つのデータセットから自在に抽出できるような データ・マネージメント法が望ましい。

\section{DBMSを利用したデータの管理と構築}

以上のような複雑なデータを作成するためには、過去にはもっぱら紙と鉛筆で、あるい はコンピュータ上であっても、ほほ手作業に等しいやり方でコーディングをする方法がと られてきた。こうした要求に技術的に応えることができるのが、リレーショナル・データ ベース・マネージメント・システム（以下D B M S と略す）である。次にD B M S 特徴 とイベントヒストリー・データの管理と構築に利用するさいの利点について簡単に述べ、 われわれの常磐炭砿離職者研究において実践しているデータベースの構築法について紹介 したい。

データベースの研究では、データベースは統合レコードの自己記述的な集合と定義され る[Kroenke 1995：訳 15]。これはデータベースが単なる蓄積されたデータ集合であるの みならず、デー夕間の関連性やデータの性質についての定義自体が含まれるものであるこ とを意味している。通常、データベースを利用する者は、データがどのように定義され、 どのような単位で分類され、データ間がどのように連結されているのかを意識する必要は ない。

いいかえれば、D B M S の特徵は、データおよびデータの集合間の関係性が利用者から 
みえるように（アプリケーションのプログラムとは独立して）管理できることにある。 $\mathrm{D}$ B M S では、汎用言語である S Q L を利用することによって、複数のデータからあらたな データマトリックスを構築し動的に管理・更新することが可能である。

D B M S を利用したデータ・マネージメントについて論じるために、広く普及している アプリケーションで使用される用語、D B M S の研究において使用されている用語、さら にわれわれに馿染み深い統計パッケージソフトで使用される用語について、整理をしてお くことにしたい。データマトリックスとは、ユニット（ケース）を行にとり、変数を列と して統計パッケージソフト上に構築される表であるといえよう。D B M S の概念では、 行・列に対応する概念をそれぞれアトリビュート、タップルと呼び、表をリレーションと 呼ぶ。パーソナルコンピュータで利用されているアプリケーションでは、行・列をフィー ルド、行をレコードと呼び、これらによって構成される表をテーブルと呼ぶのが通常であ る。以下では、利用者に馴染み深い呼び方である、この名称を使って説明をしていこう。

D B M S を利用するもっとも大きな利点は、データを動的に更新することができ、デー 夕の更新や削除にともなって生じるデー夕の異常を避けることができることである。たと えば、テーブルのある行が2つの事実を記録していたり、1つの行の削除が2つの独立し た事実を削除してしまうような状況である。たとえば、はじめに作成されたテーブルが 「顧客別注文リスト」のようなものであったとする。このデータから顧客番号001のデータ を削除したとする。すると、データから商品番号0001の金額が2000円であるというデータ が同時に失われてしまうことになろう。これをデータベース研究の概念では、更新時異常 と呼んでいる。さらに、このテーブルにある新しい顧客のデータを追加するとしよう。デ 一夕を入力する際には、論理的に異なる複数の事柄に関するデータを記録することを求め られることになろう。つまり、商品番号とその金額という商品に関する情報と氏名、購入 数、支払金額といった顧客の情報を同じレコードとして記録する必要がある。このことが 問題であることは、商品の金額が変わったときに、すべてのレコードについて合計金額を 更新しなければならないことからも、あきらかである。

リレーショナル・データベースの概念では、上のようなテーブルは 2 つの異なる次元の 事象を記録しているという点で設計に問題がある。このようなテーブルは非正規形のテー ブルと呼ばれる。リレーショナル・データベース研究は、こうした非正規形のテーブルに はどのようなタイプが存在し、どのような問題を生じさせるのかを解明してきた。そのも っとも基本的な解決法は、ドメイン・キー正規形という条件を満たすテーブルを作成する ことである(4)。ドメインとは、領域別の值の集合（人名の集合、会社名の集合、書名の集 合など）を意味している。リレーショナル・データベースにおけるテーブルの設計をする 際には、ドメインが他の集合の直積やべき集合であってはならない。もうひとつの概念で あるキーとは、テーブルにおける行を識別する、レコードに割り当てられた固有の属性で ある。リレーショナル・データベースにおけるテーブルは、少なくとも1つのキーが記録 されるフィールドをもつ。

つまり、リレーショナル・データベースによるデータ・マネージメントの特徴は、まず 次元の異なる事柄を複数のテーブルに分けて記録し、各テーブルに記録されたレコードに ついて固有のキーをわりあてることにある。こうして作られた複数のテーブルは、キーに よって連結することが可能である。たとえば、「顧客りスト」「商品リスト」のテーブルは、 
それぞれ顧客と商品という2つの異なる次元に属す事柄についてのデータである。それぞ れには、「顧客番号」と「商品番号」という固有のキーが割り当てられている。顧客りス トにあるフィールド「商品番号」は、「商品リスト」テーブルのキーであるため、個々の 顧客が何を買い求め、請求すべき「合計額」を知るための一覧表を作成することができる。 D B M S のもうひとつの利点は、こうしたテーブル間を連結させたクエリーを、D B M S の汎用言語である S Q L を利用して作成できることである。クエリーは両テーブルの更新 を常に反映するので、更新時異常は生じない。すでに例としてあげた商品金額の更新とい った事態が生じても、価格が変わった商品について、「商品りスト」テーブルの金額を更 新すれば、顧客に請求すべき合計金額のフィールドも自動的に更新される(5)。

\section{4. 概念化の過程とデータの設計一一常磐炭矿研究の事例から—}

以上のデータベースの概念を用いて、ライフコース研究における概念化とデータ・マネ ージメントの連結の実例を提示したい。ここで利用する事例は、実際にわれわれの研究グ ループが、常磐炭矿離職者の集計において利用しているものである。

まずライフコース研究における理論・概念化・分析モデルおよびデータ構築との連結を 示す事例を示しておこう。ライフコース研究の説明の対象は、人々がたどる人生軌道の多 様性にある。その分析にもちいられる主要な要因は、エルダーによれば次の 4 つの要素に 要約できる [Giele \& Elder 1999:9-11]。(A) 環境への適応としてみることのできる 「人間のエージェンシー」、（B）人々が身につける文化や社会的事件に遭遇する年齢を規 定する「時間的・空間的位置」、(C)人々がおかれた家族・企業などの領域における社会 関係を表す「連結しあう人生」、（D）年齢・時代・コーホートを指標とする多元的な時間 軸によって測られる出来事経験・役割移行の「タイミング」である。

ところで、われわれの関心は常磐炭磄を一斉に解雇された人々が、その後の人生におい て、どのような職業キャリアを形成し、その結果として現在どのような意識をもっている のかをたどることにある。そこでその後のキャリアの多様性に影響を与えるであろう重要 な要素を、上のエルダーによる 4 つの要因と関連づけて概念化すれば、以下のようになる。 (a ) 人々が身につけていた職能、失業直後の就職先に関する希望およびそれにもとづく 就職探索における戦略、資格取得行動、（b）離職者の出生コーホートによって規定される 閉山時の年齢それに対応した求職上の制約、(c) 離職者に対する家族による役割期待、と りわけ子どもの就学と親の扶養による負担、(d) 本人の年齢および家族に関するライフイ ベントを基準として測られる職業キャリアからの離脱タイミングである。

われわれはこれらの概念構成体を組み合わた仮説を設定したうえで、閉山後のライフコ 一スの多様性が、どのようにあるいはどの程度生じるのかを説明しようとしている。そし てこうした課題にライフイベントの生じる確率を説明するイベントヒストリー分析によっ てとりくもうとしている。そのさいに、そうした仮説群を実証するために必要となるデー 夕は、すでに述べたようなライフコース研究に特有の性質をともなうものとなる。つまり、 既にのべたライフコース研究におけるデータ構築の 4 つの特質と対応させれば、（1）世 帯と離職者個人という 2 つ水準の単位を同時に分析の対象とすることが必要であり、 （2）重要な従属変数は出生年をはじめとする暦年齢によって記述されるイベントヒスト リー・データであり、（3）子どもと親の扶養に関する役割期待と職業からの離脱過程と 
のタイミングという複数のキャリア間の関連性を重要な分析課題とし、（4）そうした出 来事経験のタイミングは閉山という歴史上の一時点からの経過年数、個人の暦年齢、家族 ライフイベントを基準とした経過年数として測られる。

こうした複雑なデータを通常のデータマトリックス上に記述していくことは不可能に近 い。以上のような概念化をもとにわれわれはD B M S を利用して次のようなデータセット を構築しようとしている。

データベース構築の基本に従ってまず、管理すべきデータを次のように分類することが できよう。もっとも大きな類別は、時間とともに変化しない属性と時間とともに変化する 属性である。前者は、性別や生育地、両親の学歴や出生年といった属性に加え、現時点に ついてのみ尋ねている意識や趣味活動といったデータが該当する。これらを固定データと 呼ぶことにしょう。これらを質問項目の内容に応じて、「基本属性」「意識」「趣味」とい ったテーブルに分割して格納することにする。これらのテーブルにおいてキーとなるのは、 個々人に割り当てられた、サンプル番号である。

後者は、ライフコースの軌跡を再構成するために収集されたライフヒストリー・データ が該当する。これをキャリア・データと呼ぶことにしたい。上述したように、ライフコー 不研究で主要な関心を占めるのは、人生を構成するさまざまな領域に生じる出来事経験で ある。われわれの調査項目でとりわけ重要な領域は、居住経歴・健康状態·職歴・子ども、 親、妻に関する家族経歴である。そのような概念化を行ったら、D B M S 上に、各領域に 対応したテーブルを用意し、そこにデータを格納するようにすればよい。

デー夕操作上ここで重要なことは、これらのテーブルには、個人が経験した出来事の 1 つを、1つのレコードとして記録することである。したがって、閉山後複数の職業に就い た経験のある者の場合は、その 1 名について複数のレコードにわたってデータを記録する。 キャリア・テーブルのキーは、したがって集合体としてのサンプル全体が経験したすべて の出来事に自動的に割り当てられた数字となる(以下 I D と略す)。個人を識別するキー は、固定データとの照合を行うための外部キーとして記録されることになる。また、個人 がどのような順番で出来事を経験したのかを特定できるよう、個人別の出来事経験順目を 記録するフィールドを作成する。

このように正規化されたテーブルを作成することによって、ライフコース・データの蓄 積において生じるさまざまな問題が回避できることがわかる。様々なキャリアに関するデ ータを記録するために作られた各テーブルに含まれる変数はわずかですむ。また、サンプ ルにおける出来事経験の最大数がいかなるものであっても、テーブル自体の設計を変更し なければならない事態は生じない。

では、このように管理されたテーブルから分析用のデータマトリックスを抽出するため には、どのような操作をすればよいのだろうか。以下で S Q L で実現されている、2つの データマトリックスの抽出法の事例を示したい。

例 1 最終職についての集計用データマトリックスの作成＼cjkstart固定データ・テーブルを 個人 I D と職数をキーとして「職歴」キャリア・データ・テーブルと照合する $\rightarrow$ 最後職 のみのデータセットが表示される $\rightarrow$ 固定データ・テーブルに「最終職ＩＤ」のフィール ドを作成し、職歴のキャリア・データ・テーブルの職業ごとにわりあてられた「職業 I D 」 
を入れる $\rightarrow 「$ 最後職 I D」をキーとして個人別の最後職データセットを抽出することが できる。

例 2 子どもの学卒が完了した時点で就いていた職業のデータセットの作成 も」テーブルから、対象者個人別にもっとも遅く学卒を経験した子どもを特定しフラグを

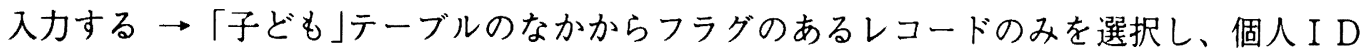
をキーにして、職歴データ・テーブルと照合する $\rightarrow$ 職歴データ・テーブルから、「子ど も」テーブルの「最終学卒年」がその職業の「開始時点」と「終了時点」の間にあるレコ ードを特定する $\rightarrow$ 固定データ・テーブルに「子ども最終学卒時職 I D」フィールドを作成 し、その出来事 I Dを入れる $\rightarrow$ 「子ども最終学卒時職 I D」をもとに個人別のデータセッ トを抽出することができる。

われわれがデータ・マネージメントの際に、D B M S を活用しているもうひとつの目的 は、常磐炭硡による社内資料や労働組合による資料といった既存資料をもとに縦断的デー 夕を構築することである。これらは、閉山以前にさかのほって彼らの職業キャリアおよび 家族キャリアを知る手がかりとなる。こうしたアーカイブデータを利用した分析手法は、 ライフコースの研究で大きな成果を上げてきたデー夕構築法である [Elder et al 1993]。 われわれの最終目的は、こうして作成された閉山前のキャリアと、われわれの面接調査で 収集された回顧法によるデータをデータベース上で連結することである。われわれのアー カイブデータには、入社時からの職業キャリア、閉山時の家族、趣味や健康状態といった さまざまな情報が記載されている。また、労働組合が発刊した書籍には、組合員の名簿が 記載されている。これには、閉山後の住所や職業などが記入されている。これらのデータ を連結することにより、われわれは閉山以前から現在までにわたる数十年にわたるライフ ヒストリー・データを構築しょうとしている。

\section{5. 結び}

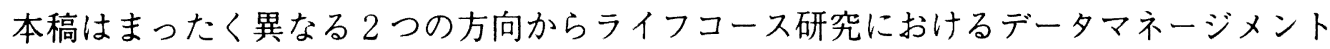
上の特質について論じてきた。

第一にライフコース研究におけるデータマネージメント上の課題について、技術的な観 点から $1 つ の$ 解決策を示した。ライフコース・パースペクティブの発展は、実証研究で不 可欠である測定法、分析技法、データマネージメントという 3 つ側面での䪊によって 支えられている。この研究の特色は、これらの技術的な革新が、それぞれ異なる経路での 発展をとげながら、相互作用しつつこのパースペクティブの発展に寄与していることにあ る。本稿では、ライフコース研究の理論的特徵が必然的に要求した複雑なデータの蓄積と 抽出が、コンピュータによるデータマネージメント技術の向上によっていかに可能になる のかを示してきた。

第二にここではライフコース研究の理論的特徴をデー夕にみられる特質という観点から 論じた。その理論的特徵は、まず以下のようなライフコース研究における分析枠組みに反 映される。すでに論じたようにライフコース研究では（1）複数の分析単位を同時に扱い （2）イベントヒストリー・データによって表現される出来事経験を分析対象として（3） 
異なるキャリア間の関連性を（4）複数設定された時間を軸として説明する。こうした他 の研究にはみられない特徽がデータの特質に反映されることはいうまでもない。ライフコ 一スの研究者は、デー夕を構築するさいに予め分析においてこれら 4 つの次元それぞれを 構成する要素が何であるかを適切に概念化し、次元間をどのように連結するのかを意識す る必要がある。そうした過程において、適切なデータベースを設計することは、技術的・ 方法論的な課題であると同時に理論的課題ともなる。適切なデータベースを構築するため には、どのような領域について集計を行うべきか、どのような単位が分析の対象となるの かを、入念に検討しなければならない。データベースの設計を考えるという純粋に方法的 な作業の過程で、研究者はそれぞれの分析テーマや対象に特有な概念化を必然的にせまら れるのである。

註

(1) こうしたワークショップでの報告は入手が困難である場合が多く、インターネット上で散見される 公開されている草稿には引用が禁じられているものがあるため、ここでは明示的な引用を控えた。

(2) カサレッチョ・プロジェクトではデータマネージメント用に、CA S A とよばれる専用のソフトを 開発している。このソフトで扱うデータは、リレーショナルデータベースの概念にもとづいて設計さ れているといえるが、ソフトは独自に設計されたものでありリレーショナルデータベースではない。

(3) 歴史人口学に扔ける宗門帳の研究では、歴史的史料からデータを構築していくためのインターフェ 一スを提供するソフトが開発されている[森本 1999]。

(4) その他の非正規形のタイプについての概説は、増永 [1990] を参照するとよい。

(5) D B M S を利用することのもうひとつの大きな利点は、ネットワークを介して複数の利用者が同時 にデータの更新・抽出をできることである。そのため複数の研究者が同時にデータを共有する共同研 究に適している。

Bengtson, Vern L. and Katherine R. Allen 1993 "The Life Course Perspective Applied to Families Over Time" Pauline G. Boss et al (eds.) Sourcebook of Family Theories and Methods, Plenum Press, Chapter 19 pp.469-499.

Brückner , Erika and Karl Ulrich Mayer 1999 "Collecting Life History Data : Experiences From the German Life History Study" Janet Z.Giele and Glen H. Elder Jr (eds.), Methods of Life Course Research Sage, Chapter 7 , pp.152-179.

Elder, Glen H. Jr. \& Janet Z. Giele 1999 "Life Course Research : Development of a Field" Methods of Life Course Research Sage Chapter 1 pp.5-27.

Elder, Glen H. Jr.,Eliza K. Pavalko and Elizabeth C. Clipp 1993 Working With Archival Data Sage.

Freedam, Deborah, Thornton, A, Camburn. D., Alwin, D.F., \& Young-DeMarco, L. 1988 "The Life History Calender : A Technique for Collecting Retrospective Data", Sociological Methodology 18 pp.37-68.

Heaton, Tim B. and Vaughn R.A.Call. 1995 "Modeling Family Dynamics with Event History Techniques" Journal of Marriage and The Family 57 pp.1078-1090.

Karweit, Nancy and David I. Kertzer 1998 "Data Organization and Conceptualization" Janet Z. Giele and Glen H. Elder Jr. (eds.) Methods of Life Course Research Sage Chapter 4, pp.81-97.

Karweit, Nancy and David I. Kertzer 1986 "Data Base Management for Life Course Family Research" Current Perspectives on Aging and The Life Course ,JAI Press, pp.167-188.

Karweit, David and Dennis P. Hogan. 1989 Family , Political Economy, and Demographic Change, The University of Wisconsin Press.

Kroenke, David M. 1995 Database Processing Fundamentals, Design and Implementation, Prentice-Hall,Inc (D. M. クロエンケ 栗原潔訳 『データベース処理』トッパン 1996) 
正岡寛司・藤見純子・嶋崎尚子・澤口恵一編著 1998 『炭砿労働者の閉山離職とキャリアの再形成 PART I」早稲田大学人間総合研究センター・早稲田大学社会学研究室.

正岡寛司・藤見純子・嶋崎尚子·澤口恵一·白井千晶·矢野佐和子編著 1999 『炭砿労働者の閉山離職 とキャリアの再形成 PART II」早稲田大学人間総合研究センター・早稲田大学社会学研究室.

增永良文 1990 『リレーショナル・データベースの基䃈』オーム社

森本修馬 1999 「統計分析を目的とした近世史料のデータベース化一入力・データ利用インターフェイ

ス」「日本研究」 19 国際日本文化研究センター pp.265-276

中道實 1997 『社会調査方法論』恒星社厚生閣

Otto, Luther B. and Vaghn R.A Call. 1990 "Managing Family Data on Multiple Roles and Changing Statuses Over Time" Journal of Marriage and the Family, 52. pp.243-248.

Scott, Jaqueline and Duane Alwin 1999 "Retrospective Versus Prospective Measurement of Life Histories in Longitudinal Research" Janet Z. Giele and Glen H. Elder Jr. (eds.) Methods of Life Course Research Sage, Chapter 4, pp81-97.

付記 本研究は平成11年度文部省科学研究費補助金の助成による成果の一部である。 